lower molar with only four simple spaces, one in front of the others, the anterior representing the front triangle, the second the normal second and third, and the third the normal fourth and fifth triangles, here opposite and coalesced with each other. Outer and inner re-entrant angles about equally deep, as they are in the second molar, which has the usual Evotomys pattern. Last molar with its outer re-entrants much deeper than usual, nearly as deep as the inner ones.

Dimensions of the type (measured in the flesh by $\mathrm{Mr}$. Gordon Smith) :-

Head and body $79 \mathrm{~mm}$. ; tail 54 ; hind foot 17.5 ; ear 10 .

Skull : greatest length 24.3 ; basilar length 20.7 ; zygomatic breadth $14 \cdot 6$; nasals $7 \cdot 2 \times 3.3$; interorbital breadth 3.9 ; breadth of brain-case 10.3 ; height of brain-case from basion 6.5 ; palate length 11 ; diastema 6.8 ; palatal foramina $4.2 \times 1.4$; antero-posterior length of bullæ 5 ; length of upper molar series (crowns) 5 , of $m^{3} 1 \cdot 6$.

Hab. Kobe, Hondo. Alt. $650 \mathrm{~m}$.

Type. Male. B.M. no. 5. 3. 3. 49. Collected 24th February, 1904. One specimen only.

"Under pine-trees, in bamboo-grass."-R. G. S.

This vole, representing a new subgenus, forms a most interesting addition to the known fauna of Japan, and I have much pleasure in connecting its donor's name with it.

LXIV.-Notes on Eastern Heterocera, with Descriptions of new Genera and Species. By Colonel Charles Swinhoe, M.A., F.L.S., \&c.

\title{
Family Syntomidæ.
}

Euchromia plagosa, nov.

․ Frons white, tegulæ orange; patagia and band at base of abdomen greyish yellow, next segment black, the third metallic blue with a white spot in the middle, the next two orange, intersected by a black line, the last two black with blue bands in them: fore wings with some metallicblue marks at the base, both wings with similar marks at the ends of the cells; spots white, a short longitudinal mark below the cell near the base, two spots in and below middle of cell (the latter the larger), two between veins 3 and 5 , and one below vein 6 : hind wings with a short subcostal white 
streak near the base and a discal band divided by the veins into three white spots.

Expanse of wings $1 \frac{8}{10}$ inch.

Neu Pommern, Kinigunang; one example.

Nearest to E. cyantis, Meyrick, Trans. Ent. Soc. 1889, p. 457, from N. Guinea.

\section{Euchromia shortlandica, nov.}

․ Black ; frons and first segment of abdomen greyish yellow, the latter with a blue spot in the middle; head and thorax with metallic-blue marks; second and third segments of abdomen metallic blue with black bands, the remaining segments crimson with black bands: fore wings with some blue marks at the base; both wings with blue marks at the ends of the cells, white semihyaline spots as in E. creusa, Linn.

Expanse of wings $1 \frac{9}{10}$ inch.

Shortland Island, Salomons.

\section{Euchromia salomonis, nov.}

q. Head and body very similar to the preceding species, but the first segment of the abdomen has two brown patches, and is without the metallic-blue middle spot; the spots on the fore wings are larger, there is a white streak below the upper discal spot, the lower middle spot joins the subbasal streak and runs in broadly nearly to the base; on the hind wings the basal hyaline band is divided into three spots by the veins as usual, but the upper one is much the longest and the outer discal band is very large.

Expanse of wings 2 inches.

Isabel Island, Salomons.

\section{Euchromia collaris, nov.}

§. Black; frons white and coxæ white; tegulæ scarletorange; head and thorax black with metallic-blue markings ; abdomen with the first segment half black and half scarletorange, next two metallic blue with black bands, the fourth black, and the remainder crimson with black bands : fore wing with blue markings at the base, a wedge-shaped hyaline white spot in the middle of the cell, a thicker and larger spot below it, the upper portion of it running thickly to near the base of the wing; four longitudinal spots on the disk, two between veins 3 and 5 , a narrow one below these which rearly reaches the lower middle spot, and the usual 
spot below vein 6 : hind wings with the basal and discal bands joined together, making nearly the whole wing hyaline, leaving a square black spot at the end of the cell, and an outer marginal black band which is thickened at the apex and at the anal angle of the wing.

Expanse of wings 2 inches.

Shortland Island, Salomons.

\section{Family Lithosiidæ.}

\section{Phaosia brunnea, nov.}

$\delta$ q. Head, thorax, and abdomen dark brown, anal tuft of abdomen yellow: fore wings with the ground-colour pinkish grey, covered with brown suffusion in parts and several brown longitudinal streaks, the most prominent being two short streaks following each other beyond the cell, one at the apex and another on the costa before the apex : hind wings uniform brown, yellowish at the tips, no markings. Underside of a uniform pale slaty brown : fore wings with short pale streak on the costa beyond the middle and another along the hinder margin : body below white; legs smeared with white, tarsi with white rings.

Expanse of wings, of 8 , +1 inch.

ơ, Sarawak, Borneo (Moore Coll.). In B. M.

q, Padang, W. Sumatra.

\section{Genus Ctenane, nov.*}

Proboscis fully developed; palpi porrect, extending about the length of head, the second joint thickly scaled; antennæ of male bipectinate, the apical third ciliated; hind tibiæ with two pairs of spurs: fore wing short and broad, vein 2 strongly curved from angle of cell, 3 from before angle, 4 and 5 from angle, 6 from below upper angle, 7, 8, 9, and 10 stalked, 10 from beyond 7 ; 11 from cell, oblique: hind wings with veins 3 and 4 stalked, 5 from well above angle, 6 and 7 stalked, 8 from middle of cell.

\section{Ctenane labuana, nov.}

§. Head, thorax, and abdomen greyish white tinged with brown; palpi blackish except at the tips: fore wings grey-white irrorated with brown and blackish; a subbasal black point below costa, antemedial black points below costa and above vein 1 ; a diffused medial fuscous-brown band,

* I owe the diagnosis of this genus to Sir George Hampson. 
attenuated at the middle and broadening to costa and hinder margin ; an ill-defined postmedial line, oblique from costa to vein 4 , then incurved, with black points on it below costa and above and below vein 2 ; outer area diffused with brown, except at apex, and with traces of a sinuous submarginal line: hind wings very pale fuscous.

Expanse of wings $\frac{1}{2}$ inch.

Labuan, Borneo.

\section{Family Limacodidæ.}

\section{Ceratonema fusca, nov.}

. Head and collar dark brown; body and fore wings pale brown with a slight pinkish tinge; abdomen with brown segmental bands: fore wings with the central upper area suffused with dark brown, forming a large suffused patch; a transverse, recurved, sinuous brown line beyond the middle, running through the outer limit of the brown suffusion; a submarginal paler line with indistinct pale brown streaks running from it to the outer margin: hind wings pale greyish brown without markings. Underside of a uniform pale greyish brown without markings, but with a blackishbrown suffused space in the central upper area of the fore wings.

Expanse of wings $\frac{9}{10}$ inch.

Khasia Hills.

There are two examples from the Khasia Hills in the B. M., Limacod drawer no. 15, unnamed.

\section{Family Lasiocampidæ.}

\section{Crostogastria pruni.}

Bombyx pruni, Linn. Syst. Nat. i. p. 498 (1758).

Odonestis pruni, Kirby, Cat. Moths, p. 811 (1892).

$1 \delta$, Khasia Hills.

1 \&, Jaintia Hills.

Differ in no way from the European insect, except in being rather duller in colour.

\section{Arguda vita.}

Odonestis vita, Moore, Cat. Lep. E. I. C. ii. p. 424, pl. xii. a, fig. 4 (1859).

1 ภ, 1 ㅇ, Calcutta, October 1889.

The type came from Java. These examples stood in my collection as $O$. bheroba, Moore, but I have now examined 
them with the types in the B. M.: the latter is a very different insect with straight transverse lines and seems to be very rare; the type is in Coll. Staudinger and the co-type in the B. M. My Calcutta examples of vita do not differ in any way from the Javan type.

\section{Stenophyllodes khasiana, nov.}

o. Palpi much shorter than in S. sikkima, Moore, colour of a nearly uniform brownish fawn with a tinge of pink; branches of antennæ pale blackish; collar pale and somewhat ochreous; body without markings: fore wings pale towards outer margins and less well clothed; hind wings slightly darker than the fore wings; both crossed by numerous indistinct waved lines slightly darker than the ground-colour; a black dot at the end of cell of fore wings. Underside paler, the fore wings more pink tinged and without markings; the hind wings with two short brown lines running down from the costa near the base, and three indistinct sinuous lines across the disk.

Expanse of wings 2 inches.

Khasia Hills.

A smaller insect than S. sikkima, with the outer margin more deeply crenulate.

\section{Family Trifidæ. \\ Euplexia fasciata.}

Xylophasia fasciata, Leech, Trans. Ent. Soc. 1900, p. 68.

Khasia Hills; common.

The type from Western China is in the B. M. and is identical with the Assam examples.

\section{Euplexia repetita.}

Apamea repetita, Butler, Cist. Ent. iii, p. 133 (1885).

Khasia Hills ; one example.

The type came from Yokohama.

\section{Radinacra albosignata.}

Caradrina albosignata, Oberth. Etud. d'Ent. r. p. 72, pl. iv. fig. 1 (1880).

Khasia Hills, 10 .

: The type came from Amurland; there are several examples in the B. M. from Central and Western China; it is closely 
allied to $R$. lineosa, Moore, a common Indian insect, but the transverse lines on the fore wings are closer together and the reniform is of a different nature.

\section{Family Acontiidæ.}

Metachrostis brunneiplaga, nov.

of + . Palpi, head, and thorax dark pinkish brown, palpi with the last joint pale: fore wings pale pinkish brown, a brown patch at the base with nearly upright outer margin, a large brown costal patch extending from beyond the middle nearly to the apex, some brown spots on the costa; indications of a medial double line, also of three sinuous lines below the patch, and three large pale brown spots on the outer margin; marginal line very thin and interrupted by the reins; cilia with a pale brown interline: hind wings pale pinkish brown, paler than the fore wings, with an indistinet pale brown marginal line.

Expanse of wings $\frac{7}{10}$ inch.

Khasia Hills ; many examples.

Not unlike M. brunnea, Leech, Trans. Ent. Soc. 1900, p. 157, from Central China, but that form has no basal band.

\section{Motina requalis.}

Motina aqualis, Walker, xxvii. 12 (1863).

Khasia Hills.

The type from Sarawak, Borneo, is in the B. M.

\section{Family Quadrifidæ.}

\section{Blasticorhinus rivulosa.}

Thermesia rivulosa, Walk. xxxiii. 1060 (1865).

Acantholipes quadripuncta, Swishoe, Ann. \& Mag. Nat. Hist. (7) ix. p. 423 (1892).

The type from Moulmein is in the B. M. The type of quadripuncta, also in the B. M., is from Palawan. I have it also from the Nilgiri Hills, and there are examples in the B. M. from Ceylon and from Java.

\section{Family Focillidæ.}

Avitta surrigens.

Oroba surrigens, Walker, Journ. Linn. Soc., Zool. vii. p. 81 (1864).

Andaman Islands (Bingham).

The type from Sarawak is in Mus. Oxon.; in Cat. Het. 
Mus. Oxon. ii. p. 194, I made it a synonym of A. subsignans, W alker, but I wrongly identified that species; the fore wings are rounder, it is paler in colour, the transverse markings are entirely absent, and there is a large round blackish spot at the end of each cell. I have subsignans from Sumba, Perak, Queensland, Andamans, Bombay, and the Nilgiris; I have surrigens from Gilolo, and it is in Mus. Oxon. from Sarawak, Flores, Sula, and Aru.

\section{Genus Biethantha, Walker.}

Boethantha, Walker, xxxiii. 982 (1865).

Seneratia, Moore, Lep. Ceylon, iii. p. 202 (1885).

\section{Bœethantha bisignata.}

Bothantha bisignata, Walker, xxxiii. 983.

Ctypansa bocanidia, Butler, Ann. \& Mag. Nat. Hist. (5) x. p. 231 (1882).

Ceylon, Nilgiri Hills.

Walker's type from Timor is in Mus. Oxon., also an example from Ceylon; the type of bocanidia, from Duke of York Island, is in the B. M. I have it in my collection from Saparæa, New Guinea, Kina Balu, Mouklek Mountains (Siam), Nilgiri Hil s, and Ceylon. It is not mentioned in Hampson's 'Moths of India.'

\section{Adrapsa atratalis, nov.}

of . Dark brownish black, very uniform in colour: fore wings with a white dot at the end of the cell; transverse lines white, sinuous, antemedial, postmedial, and submarginal; the first bends inwards close to the hinder margin, the second bends outwards, the submarginal line runs from the costa into the inner side of a very large subapical, pure white, almost square patch, and is continued in a row of white dots to the hinder margin; outside the patch on the margin are four pure white lunules, and the black cilia have white spots: hind wings with a medial line which does not reach the c. sta, a submarginal row of white dots, and indications of a marginal white line. The underside is paler, having some white suffused scales on the wings: on the fore wings the cell-spot and postmedial line are bordered inwardly with black, and some white suffusion in place of the subapical patch; on the hind wings are three transverse white lines-antemedial, medial, and discal-the first two rather close together, all inwardly bordered with black; both 
wings with whitish marginal lunules and white spots on the cilia.

Expanse of wings $1 \frac{9}{10}$ inch.

Khasia Hills. In B. M.

At page 162 of this vol. by mistake I described the female of this insect as the female of $A$. curiosalis, but I have found both sexes of this form from the Khasia Hills in the B. M., the antennæ of the male differing from the antennæ of curiosalis, with large scale-tooth on outer side just beyond basal joint, the shaft then curved, with small scale-tufts on the joints and fascicles of cilia; at one fourth from base the shaft is dilated into a large knot.

There is also an example in the B. M. from Western China (Leech Coll.).

\section{Family Hypenidæ.}

\section{Bomolocha obductalis.}

Hypena obductalis, Walker, xvi. 56 (1858).

Bomolocha obductalis, Swinh. Cat. Het. Mus. Oxon. ii. p. 212 (1900).

Hypena vestita, Moore, Lep. Ceylon, iii. p. 221, pl. clxxvi. fig. 10 (1885).

Khasia Hills ; fairly common.

The type, marked "India," is in Mus. Oxon., the type of vestita from Ceylon is in the B. M. ; they cannot be separated. It is also in the B. M. from Sikkim. The allied form eductalis, Hmpsn., the type of which from Sikkim is in Coll. Elwes, is the commonest form in the Khasia Hills : flexuosa, Moore, which Sir George Hampson puts as a synonym of obductalis, is in my opinion quite distinct; I have it from Simla, Darjiling, and Kulu.

\section{Genus Anepa, nov.}

Palpi oblique ; third joint smooth, a little more than half the length of the second: fore wing long and narrow, excavated from apex to vein 4 , where there is a rather prominent angle; antennæ ciliated and abdomen with dorsal tufts, as in the genus Hypena, but the shape of the wings and upturned palpi clearly separate it from that genus and all its subdivisions.

Type, oxydata, Hmpsn. (Hypena oxydata), Journ. Bombay N. H. Soc. xi. (4) p. 707 (1898). 


\section{Anepa doda.}

Hypena doda, Swinhoe, Ann. \& Mag. Nat. Hist. (7) ix. p. 180 (1902).

Khasia Hills.

The type from Goping, Perak, is in the B. M.; also examples from Penang, Formosa, and Sikkim.

\section{Family Geometridæ.}

\section{Medasina leledaria, nov.}

$\delta$. With the ground-colour ochreous grey, irrorated with olive-brown atoms, and spots, bands, and markings all olivebrown ; antennæ, palpi, frons, head, and thorax dark olivebrown; abdomen paler: wings with a rather large spot at the end of each cell ; subbasal, medial, and discal transverse bands, all more or less duplex and incomplete, showing best towards the costal and hinder margins ; the last band curved outwards below the costa and inwards before the hinder margin, and dentated in the middle on both wings; a submarginal white dentated line and a marginal black crenulated line. Underside pale grey, nearly white, with darker grey irrorations, blackish cell-spots, and a broad blackish discal band, attenuated hindwards on both wings ; tarsi with white, bands.

Expanse of wings $2 \frac{1}{10}$ inches.

Khasia Hills.

There is an example from Bhutan in the B. M. in Boarmid drawer no. 127.

\section{Boarmia properata.}

Boarmia properata, Walker, xxi. 376, o (1860).

Boarmia acaciaria, Hmpsn. (part.), Moths India, iii. p. 264 (1895).

Boarmia cornaria, Swinh. (part.), Cat. Het. Mus. Oxon. ii. p. 290 (1900).

Thyetmyo, Burma.

The type (a male, said to be from North Hindustan) is in the B. M. I have both sexes from Burma and Perak, and find that it is quite distinct from either acaciaria or cornaria ; the former has the antennæ of the female almost simple, whereas in the female of properata the antennæ are strongly pectinated for three fifths the length, as in the male, but the pectinations not so strongly pubescent; it comes under Warren's subgenus Carecomotis (Nov. Zool. iii. p. 402); the female of cornaria has also pectinated antennæ. I have examples from Ceylon and South India; the pectinations are, however, much shorter, and it is smaller and differently coloured. 


\section{Heterabraxas rufonotaria.}

Metabraxas rufonotaria, Leech, Aun. \& Mag. Nat. Hist. (6) xix. p. 451 (1897).

2 , Khasia Hills.

The type came from Western China; the markings on the Khasia Hill examples are darker black, otherwise there is no difference.

\section{Family Thyrididæ.}

Rhodoneura candidatalis, nov.

$\delta$. Frons white; head and thorax brown, the latter white hindwards; abdomen and wings white, the former with indistinct chocolate-grey bands: fore wings with the costal space smeared with pale chocolate-brown, with many striations of the same colour, these striations extending to the base of the wing and on the basal half of the hinder margin; two duplex discal lines of the same colour, intertwined, near each other on the costa near the apex, gradually separating to the hinder margin, where the first is a little beyond the middle and the other near the angle: hind wings with three similar duplex lines, the first near the base, the second across the middle, and the third across the disk. Underside same as upperside, the lines more pronounced.

Expanse of wings $1 \frac{2}{10}$ inch.

Silchar, Cachar.

\section{Rhodoneura mollicellalis, nov.}

๙. Palpi, frons, head, and collar bright chestnut-red; body and wings of a unifurm ochreous fawn-colour; abdomen with the penultimate segment white, the ultimate black, the anal tuft white: both wings evenly irrorated and striated with minute pale black marks ; a pale subapical mark on the costa of fore wings, with two pure white spots obliquely below it, these black dots in a line near the outer margin above vein 5 ; some black dots in the centre and near outer margin of hind wings ; cilia of both wings dull chestnutred. Underside paler and more ochreous, the white costal subapical spots on the fore wings confluent, forming a little white patch, the striations and irrorations more sparse, but both wings have many larger black dots; legs white beneath.

Expanse of wings $1_{1}^{\frac{3}{0}}$ inch.

Khasia Hills; a fine series.

The three black dots above vein 5 near the outer margin of the fore wings are not always constant-in one example there are only two and in another they are all absent. 
Rhodoneura turbatalis, nov.

๙ิ. Palpi, frons, head, and collar chestnut-red; body and wings pale pinkish grey; abdomen with a brown dorsal band and a prominent blackish-brown spot on the penultimate segment, ultimate segment and anal tuft concolorous with the body: wings rather sparsely covered with brown even striations; fore wings with the outer half suffused with brown, except for a small space on the hinder margin beyond the middle; hind wings with a broad suffused brown medial band; a triangular ochreous-white patch on the costa near the apex, including two small brown costal spots; a black dot above vein 5 near the outer margin ; marginal line brown; cilia on fore wings ochreous, with brown patches; cilia on the hind wings ochreous brown, without patches. Underside as above, but the ground-colour is nearly white and there is no band on the hind wings; legs concolorous with the body, without markings.

Expanse of wings $1 \frac{2}{10}$ inch.

Khasia Hills ; a fine series.

Both the above are allied to $R$. atripunctalis, Walker, from Java, but are quite distinct.

\section{Family Hydrocampidæ.}

\section{Piletocera chrysorycta.}

Semioceros chrysorycta, Meyrick, Trans. Ent. Soc. 1884, p. 320.

Nacoleia contingens, Moore, Lep. Ceylon, iii. p. 273, pl. clxxix. fig. 8 (1885).

Meyrick's type came from Duaringa, Queensland, Moore's from Ceylon: I have it from both localities and also from Sarawak, and I cannot see how they can be separated; they have not a character which is not common to both.

\section{LXV.-Notes on Subspecies of European Shrews (Sorex and Neomys). By G. E. H. Barrett-Hamilton.}

In continuation of my studies of European and British Mammalia in the British Museum of Natural History I find amongst the shrews two very distinct subspecific forms, the extremes of which are very clearly marked. The one a water, the other a common shrew, were trapped by Mr. C. G. Danford in the same region in the Southern Carpathians at Ann. \& Mag. N. Hist. Ser. 7. Vol. xv. 


\section{$2 \mathrm{BHL}$ Biodiversity Heritage Library}

Swinhoe, Charles. 1905. "LXIV.-Notes on Eastern Heterocera, wit

Descriptions of new Genera and Species." The Annals and magazine of natural history; zoology, botany, and geology 15, 495-505.

https://doi.org/10.1080/03745480509442839.

View This Item Online: $\underline{\text { https://www.biodiversitylibrary.org/item/63423 }}$

DOI: https://doi.org/10.1080/03745480509442839

Permalink: $\underline{\text { https://www.biodiversitylibrary.org/partpdf/59275 }}$

\section{Holding Institution}

University of Toronto - Gerstein Science Information Centre

\section{Sponsored by}

University of Toronto

\section{Copyright \& Reuse}

Copyright Status: NOT_IN_COPYRIGHT

This document was created from content at the Biodiversity Heritage Library, the world's largest open access digital library for biodiversity literature and archives. Visit BHL at https://www.biodiversitylibrary.org. 